\title{
United Nations
University INTECH
}

Institute for New Technologies

\section{Discussion Paper Series}

\author{
\#2004-16 \\ Growth of Employment and the Adoption of E-business
}

Kaushalesh Lal

August 2004 



\title{
GROWTH OF EMPLOYMENT AND THE ADOPTION OF E-BUSINESS
}

\author{
Kaushalesh Lal*
}

\begin{abstract}
The paper investigates the impact of the adoption of e-business technologies on workforce displacement. A case study approach has been applied to examine both direct and indirect employment associated with the adoption and production of new technologies. The study covers a wide spectrum of large firms ranging from skill intensive sectors such as electronic goods manufacturing, to labour intensive sectors such as garment manufacturing. E-business technology producing firms were included in the study. The study did not find any evidence to support the argument that adoption of e-business technologies leads to a loss of jobs. The results do indicate, however, that the adoption of e-business technologies might result in the restructuring of business organizations. The study further reveals that the adoption of new technologies creates substantial employment in the form of new business activities, at the expense of a few jobs in existing business processes.
\end{abstract}

Keywords: E-business, Employment, Developing Countries, Large Corporations

\section{UNU-INTECH Discussion Papers \\ ISSN 1564-8370}

Copyright (@ 2004 The United Nations University, Institute for New Technologies, UNUINTECH

\section{UNU-INTECH discussion papers intend to disseminate preliminary results of the research carried out at the institute to attract comments}

\footnotetext{
* Researcher at United Nations University-Institute for New Technologies; Email: klal@intech.unu.edu. Comments from an anonymous referee are gratefully acknowledged. Owing to data constraints a number of the comments could not be absorbed in the paper.
} 



\section{TABLE OF CONTENTS}

1. INTRODUCTION

2 BACKGROUND OF SAMPLE FIRMS AND THEIR TECHNOLOGICAL PROFILES. 11

2.1 CASE STUDIES

2.1.1 Technology Producers 12

2.1.2 Technology using firms

3. ADOPTION OF E-BUSINESS TECHNOLOGIES AND THEIR CONSEQUENCES 21

$\begin{array}{ll}3.1 \text { PRODUCERS } & 21\end{array}$

$\begin{array}{ll}3.2 \text { CONSUMERS } & 21\end{array}$

4. SUMMARY AND CONCLUSIONS 23

$\begin{array}{lr}\text { REFERENCES } & 25\end{array}$

$\begin{array}{lr}\text { THE UNU-INTECH DISCUSSION PAPER SERIES } & 27\end{array}$ 



\section{INTRODUCTION}

The employment effects of information and communication technologies (ICTs) ${ }^{1}$ have been a major cause for concern from the early stages of the development and adoption of ICTs in various economic activities. From the outset, there was apprehension that the adoption of these technologies might lead to job losses, particularly among semi-skilled or unskilled workers, through the automation of routine tasks by ICT tools programmed to handle multiple jobs (Nilsen, 1980).

Over the same period there have been many proponents of the counter-argument that ICTs would lead to the creation of many new jobs and give rise to new industries and services (Talero and Gaudette, 1995). Rada (1982) and Kuwahara (1984) found that the adoption of IT leads to the creation of new jobs in some production processes, and a loss of workplaces in other activities at the enterprise level from a static perspective. The authors also found evidence of the emergence of new firms dealing with ICT related activities, external to the existing enterprises. For instance, several new consultancy firms have emerged in the garment sector to provide technical input and technological support to garment manufacturing firms. Although they provide training and consultancy services in other manufacturing technologies used within the sector, these new firms tend to concentrate on the new ICT-based technologies.

The adoption of ICTs in labour-intensive activities is expected to result in the displacement of labour, while creating a few new jobs for skilled workers needed to maintain the ICT tools. The adoption of ICTs may be neutral in labour use if it is possible to achieve expansion of markets for existing products, or to create markets for new products manufactured on the same assembly lines as a result of increased efficiencies brought by ICTs. This may apply at the enterprise level itself, but even more at higher levels of aggregation. Where market expansion is possible, the adoption of ICTs could lead to the creation of employment for skilled workers and if the market expands fast enough, there may not be a loss of jobs for unskilled workers. However, firms may need to undergo some organizational changes and workers may require training to upgrade their skills in order to use ICT tools effectively. The findings of several studies that deal with employment aspect of ICTs are presented below.

\footnotetext{
1 The term Information Technology (IT) was widely used in studies carried out before 1990s as the integration level of communication technologies with information technologies was not very high. Subsequently, and particularly following the introduction of the Internet in the public domain, communication technologies became increasingly embedded with information technologies. Consequently we refer to Information and Communication Technologies (ICTs) throughout most of this paper, with the exception of references to studies carried out before 1990.
} 
Freeman and Soete (1985) found no evidence of an adverse relationship between employment and the adoption of IT. Their conclusions are based on several other studies (Leontief and Duchin, 1983; Kuwahara, 1984; Lawrence, 1984) carried out in developed countries (US, Canada, and Japan). The study by Leontief and Duchin (1983) is a very comprehensive one. The authors analysed 89 individual sectors, comprising almost the entire industrial spectrum of the US economy. They concluded that there will be no overall labour surplus due to the adoption of IT at the industry level even though the employment in some individual enterprises may suffer. However, it was predicted in the study that the structure of the labour force in terms of skills and sectoral distribution might have to undergo some fundamental changes. A study by Lawrence (1984) found a positive correlation between the industrial adoption of IT and employment growth in Japan.

Peitchinis (1984) studied the employment effects of the introduction of computer equipment and office automation in a number of manufacturing sectors ranging from food to oil companies in Canada. The author rejected the prediction of mass unemployment as a result of IT adoption. On the contrary, his case studies suggest that the employment effects of IT adoption have generally been positive. The study is based on firm level data, but the findings apply primarily to firms that had not reached a saturation point in the demand for their products. Such firms could generate employment by increasing their production capacity and by adopting IT tools. The author observed, however, that there could be employment displacement as a result of adoption of IT in matured industries and in particular occupations. Although the sample firms covered by Peitchinis were engaged in manufacturing of goods, the study concentrated mainly on the introduction of computer equipment in office automation. Therefore, the results cannot be interpreted as representative of effects of IT adoption in manufacturing.

A study by Kuwahara (1984) emphasized the positive employment-generating effects of a range of new technologies in the Japanese economy. Although these new technologies included biotechnology and aerospace, the main emphasis was on IT. Microelectronics- based technologies (technologies that are used to manufacture hardware of information systems, communication equipment, audio/visual devices, and other electronic products) and IT were seen as creating multiplier effects in other industries and services. The study presents detailed estimates of job creation effects in high technology industries in Japan. Kuwahara presents the estimates categorized into various skills levels. The findings suggest that engineers are likely to be in greater demand than non-technical workers in high technology industries. Several other studies (Rada, 1982; James, 1994; Rahim and Pennings, 1987) pointed to the possibility of structural change in employment. Rada (1982) found evidence of a reduction of jobs at the supervisory level. At the same time, IT tools require a highly skilled workforce for the implementation and use of microelectronic-based systems (Ayres, 1991; James, 1994). LDCs 
have experienced similar employment effects of IT. Acero (1995) reported the changes in employment structure in a study of the Brazilian textile industry. Acero found that industrial automation and new organizational technologies are seen as contributing to higher employment levels in the technical and managerial category, while the number of occupational categories and labour-intensive tasks is decreasing with the introduction of IT. Sim and Yong (1995) found similar results in their study of the Malaysian telecommunications industry.

In recent years, Doms et al. (1997) have examined the correlation between the share of nonproduction workers and the use of advanced technology. Consistent with the complementarity of skill intensity and the use of advanced technologies, the authors found a positive correlation between the two variables. A study of 402 plants in Britain by Kramarz (1998) suggests that the introduction of computers in plants is associated with an increase in the share of white-collar workers at the expense of unskilled workers. Card et al. (1997) investigated the effect of computer use on the employment rates of various age and education groups. Based on their knowledge of the institutional environment of the three countries (US, Canada, France), they expected to find the greatest negative impact of IT on employment in France. Their hypothesis was that if a similar negative demand shock were to affect less-skilled workers in all three countries, the result in the US, given its labour market flexibility, should primarily be a decline in the relative wages of less-skilled workers. In France, where labour markets are relatively inflexible, the shock should largely result in a decline in the relative employment of less- skilled workers. However, the results do not seem to show this pattern. In the case of the US, results show that groups that use computers most, categorized by age and education, record an intensive increase in group-employment rates. In the case of France (female workers) and Canada, there is no significant relationship between computer use and employment. The US results are based on data extracted from the Current Population Survey (CPS) of 1979 and 1989, while Labour Force Survey (conducted in 1982 and 1989) data were used for France. The data for the Canadian sample were taken from the Survey of Work History, 1981 and Labour Market Activity Survey, 1988.

The findings of the studies discussed above are by and large related to developed economies. Having no a priori knowledge of any study carried out in a labour surplus economy such as India, this study examines direct and indirect impact on employment emanating from the production and the adoption of ICTs in India. The case of India is quite relevant because the country has made its presence felt in global software production but continues to face serious unemployment problems. A long series of data are needed to examine the impact of the adoption of ICTs on employment and it is extremely difficult to collect data on workforce ${ }^{2}$ for a

${ }^{2}$ It may be mentioned that no public domain, privately owned data bases, or government surveys provide data on employment in India. 
long period of time. Hence, we have preferred to use the case study method to study the impacts, on employment, of the adoption of ICTs. These are subsequently referred to as "ebusiness technologies' to reflect the focus of the study on the adoption of ICTs in business organizations. Since the effect on employment is expected to be more visible in large firms, we have selected a few top firms in the skilled as well as labour-intensive sectors. While investigating the effect on employment, we have also taken into consideration the employment generated by the production of e-business technologies. We present here the case studies of top firms in three industries, namely: e-business technology production (ICT sector), consumer electronics, and the garment manufacturing industry.

The remainder of the paper is organized as follows: The sample firms are discussed in Section 2. In Section 3 we analyse the impact of the adoption and production of e-business technologies on direct and indirect employment created by these firms. The finding are summarized in Section 4. 


\section{BACKGROUND OF SAMPLE FIRMS AND THEIR TECHNOLOGICAL PROFILES.}

The sample included firms that produce e-business technology as well as those that use such technologies. Within the technology using firms, we covered two extremes of the industrial spectrum - the modern industry segment represented by consumer electronic and componentmanufacturing firms, and the traditional, labour intensive, industry represented by garment manufacturing firms. Sample firms were selected on the basis of their sales turnover over the past few years, and their location. The selection of firms located in different parts of the country would help in analysing the role of local governments in the diffusion of e-business technologies. The location of firms on the map of India is shown in Appendix II. Although national and global institutional infrastructure is not the responsibility of local governments, we hypothesized that various state governments might have played a catalytic role in providing local infrastructure and an environment conducive for the diffusion of e-business technologies. Hence, the broad distribution of sample firms within the country is considered as very important for this study.

The identification of technology producing firms, and consumer electronic \& component manufacturing firms was not difficult, as they are well known in the Indian market. Data on sales turnover and their location in the country were taken from the Capitaline database ${ }^{1}$ while employment data were collected through personal interviews with senior representative of the firms. The size of operation and other details of garment manufacturing firms were obtained from the Apparel Export Promotion Council (AEPC), a government agency attached to the Ministry of Commerce. The size and growth of sample firms since 1994-95 are presented in Table 1 whereas their product and technological profiles are presented in Appendix I.

\subsection{Case Studies}

This sub-section presents findings from three e-business technology producing firms and two top consumer electronics firms. It also discusses the causes and consequences of the adoption of e-business by the three largest garment manufacturing firms.

\footnotetext{
${ }^{1}$ The Capitaline database is maintained and distributed by M/s Capital Market Pvt. Ltd. The dataset contains information on 8000 firms and 300 variables. These firms are listed on all major stock exchanges in India.
} 


\subsubsection{Technology Producers}

We present the case studies of Wipro, Infosys, and Satyam. These firms are engaged in different sub-sectors of the ICT industry. Infosys represents the software sub-sector, while Satyam is an Internet service provider. Wipro, which has a strong presence in ICT hardware as well as software, was selected in place of Tata Consultancy Services, another top-ranking Indian company.

i. WIPRO

The WIPRO group is a conglomeration of five companies: Wipro Infotech, Wipro Technologies, Wipro Corporate, Wipro Learning, and Wipro consumer care and lighting. For the purpose of this study, we will discuss Wipro Infotech and Wipro Technologies (hereafter Wipro). Wipro Infotech was set up in 1983 to serve the domestic market in the area of ICTs, including hardware, software and services. Wipro Technologies was set up to cater for ICT related services in international markets. At present, Wipro operates from more than 200 locations. The performance of Wipro has been particularly impressive since the liberalization of the Indian economy in 1991-92. As shown in Table 1, the Compound Annual Growth Rate (CAGR) of the sales turnover of Wipro has been 59.21 percent since 1994-95.

Table 1: Size and growth of firms

\begin{tabular}{|c|c|c|c|c|c|}
\hline Firms & $\begin{array}{l}\text { Sales } \\
\text { Turnover: } \\
\text { 2003-04 } \\
\text { (Rs. } \\
\text { Million) }\end{array}$ & $\begin{array}{l}\text { Employ- } \\
\text { ment: } \\
\text { 2003-04 } \\
\text { (Persons) }\end{array}$ & $\begin{array}{l}\text { Annual } \\
\text { Growth } \\
\text { of STO } \\
\text { since } \\
1994-95\end{array}$ & $\begin{array}{l}\text { Annual } \\
\text { Employ- } \\
\text { ment } \\
\text { Growth } \\
\text { since } \\
\text { 1994-95 }\end{array}$ & $\begin{array}{l}\text { Average annual } \\
\text { expenditure on } \\
\text { e-business } \\
\text { technologies } \\
\text { (Rs. Million) in } \\
\text { 2002-03 }\end{array}$ \\
\hline \multicolumn{6}{|l|}{ Technology Producers } \\
\hline 1. Wipro & $52,080.0$ & 30,000 & 59.21 & 43.68 & -- \\
\hline 2. Infosys Technologies & $47,608.9$ & 25,634 & 70.46 & 47.72 & -- \\
\hline 3. Satyam Infoway & $2,801.1$ & 2,776 & $47.34 *$ & $42.65^{*}$ & -- \\
\hline \multicolumn{6}{|l|}{ Technology Users } \\
\hline \multicolumn{6}{|l|}{ a. Consumer Electronics $* *$} \\
\hline 4. Videocon & $47,464.7$ & 24693 & 20.96 & 9.69 & 180 \\
\hline 5. BPL & $24,764.5$ & 11413 & 20.63 & 9.61 & 200 \\
\hline \multicolumn{6}{|l|}{ b. Garments } \\
\hline 6. Orient Crafts & $7,078.4$ & 15030 & 30.05 & 16.67 & 4.7 \\
\hline 7. Gokaldas Images & $2,801.1$ & 6037 & 19.56 & 10.49 & 4.5 \\
\hline 8. Sonal Garments & $2,651.5$ & 5104 & 15.61 & 10.01 & 1.2 \\
\hline
\end{tabular}

The company has been similarly successful in the development of e-business technologies. It has recently developed DOCUSMART, an e-business solution software that helps to integrate 
all documentation related functions in the total business activities of a firm. The software has been introduced in a few companies within the traditional sectors, including tobacco and automobile industries. Realizing the need to provide an integrated business solution, rather than process and function specific tools, the company has recently developed a System Integrated Service (SIS) package as an integrated e-business solution to firms. As has been experienced by Systems and Application Products (SAP), ${ }^{2}$ e-business solutions require a lot of customization at firm level. Wipro has not only started providing integrated software solutions but provides communication infrastructure, which is one of the pre-requisites for the success of e-business technologies.

Although the company has not created any significant indirect employment opportunities, it has managed to maintain growth in direct employment at an annual rate of 44 percent since 199495. The company is currently in the process of developing business solutions for small-scale industries (SSIs). If it succeeds, it could achieve significant impacts through indirect employment. The company intends to create a dealership network to interact with end-user organizations. It already coordinates a powerful network of dealers to provide ICT hardware solutions. In the opinion of management, however, the company does not have the capacity to provide e-business solutions for firms. The company feels that economic growth in general is expected to significantly impact the diffusion of e-business technologies that have a large potential for generating employment. The company does not anticipate any adverse impacts of the adoption of e-business technologies on the employment opportunity and profitability of SSIs.

\section{ii. INFOSYS}

The company was set up in 1981 by a group of engineering graduates from the Indian Institute of Technologies. Infosys primarily develops software products and services for international markets. When interviewed, the company's managers expressed the view that a major hindrance in the diffusion of e-business technologies in Indian SSIs is the absence of an affordable and reliable communications infrastructure. ${ }^{3}$ The company is hesitant about developing e-business solutions for SSIs due to a lack of scalability of the product and the inability of SSIs to exploit the full potential of such advance technologies. However, the firm has recently developed an ebusiness software solution, FINACLE, for the banking sector that has been successfully adopted by a few Indian banks. Other well-known industrial software solutions developed by Infosys are SCM, Warehouse Management System (WMS), and Transportation Management System (TMS).

${ }^{2} \mathrm{SAP}$, a German multinational, is one of the world's leading e-business solutions providers. 
With regard to the impact of e-business technologies on low-income users, the company has very little experience as $98.5 \%$ company's business is in export markets. However, the company's direct employment has grown at $47.72 \%$ since $1994-95$, due to its success in developing software solutions. The company's e-business solutions are being used in a wide range of industrial sectors such as electronic goods manufacturing, chemical industries, automobile, and intermediate goods manufacturing firms. Unlike Wipro, the company has no immediate plans to develop e-business software solutions for the Indian SSIs. However, it may consider the development of software for large Indian corporations with adequate financial resources to improve their business infrastructure. The management of the company feels that the adoption of e-business technologies may not have an adverse impact on employment in Indian SSIs, but small firms cannot use such technologies effectively due to infrastructure related problems. Hence, the diffusion of such business solutions will not pick up unless an affordable and reliable communication infrastructure is in place.

\section{iii. SATYAM INFOWAY}

Satyam Infoway is a sister company of Satyam Computers. Although the parent company has been in existence for a fairly long time, Satyam Infoway was only established in 1996 at a time when several other ICT companies were already well established. Satyam Infoway did not focus on the existing technologies but concentrated on the Internet and related technologies and software services that were very new in the Indian market. ${ }^{4}$ The company has assumed leadership in creating e-business solutions in this area and is trying to consolidate its position in this field. It can be seen from Table 1 that the firm has experienced growth in employment and sales turnover that is comparable with other large ICT firms in India.

Apart from generating direct employment, Satyam has created huge indirect employment opportunities. At present, the company has a network of more than 1500 cyber cafés across the country. In addition it manages a huge network of dealers employing more than 7000 persons. The dealers assist clients in connecting to the Internet through the Satyam server, and provide technical help to end-users. These agencies act as single window solution providers for all the services offered by Satyam.

The company plans to significantly expand the development of e-business solutions by addressing the core bottleneck to the expansion of Internet use. Realizing that e-business solutions will not succeed without a good telecommunications infrastructure, the company has

\footnotetext{
${ }^{3}$ A study by Muller-Falcke (2001) finds that small firms in India were using ICTs in peripheral activities.

${ }^{4}$ Email and internet were launched for public on August 15, 1995 by then a public sector company, that is, Videsh Sanchar Nigam Limited (VSNL). VSNL is now a private firm owned by the Tata group, a leading industrial house in India.
} 
set up a private communication network covering sixteen major industrial cities. Another impediment in the diffusion of e-business technologies relates to establishing the authenticity of electronically transferred documents. Despite the fact that the Indian government has legitimatized electronically transferred documents, most companies do not accept such documents unless they have been signed by a competent person. At present Satyam is sole company licensed to certify and provide the electronic signature of any individual. The electronic signature can be sent along with the document or separately. The management of Satyam is of the opinion that e-business technologies are poised to both create huge employment opportunities and enable firms to do business in a more organized manner.

\subsubsection{Technology using firms}

In this sub-section we shall examine the evidence of the impact of e-business technologies on large firms that have adopted such technologies. The first two firms are in the capital and skill intensive sector, while the last three firms represent the labour-intensive sector.

\section{i. VIDEOCON}

Videocon International came into existence in 1981 and is the largest consumer electronics company in India. The major business of the company is the production of home appliances and entertainment electronics. However, in this study we have used data related to consumer electronics, specifically for home entertainment systems. With a network of eighteen manufacturing plants and 52 corporate offices in India, Videocon started using SAP e-business solutions in 1991. In the early years, the adoption of such sophisticated business solutions was not very successful due to poor communications infrastructure. In 1997, the company introduced satellite based communications technology and currently all its manufacturing plants, corporate offices, foreign offices, and plazas ${ }^{3}$ are connected on-line. In addition, the firm has a network of more than 7050 dealers throughout the country.

In recent years, the company has augmented its SAP supplied e-business solutions. The firm has embarked on technical collaborations with foreign firms located in Japan (Nakamashi, Sansui) and the USA (Telecruz Inc.). The company has its own Internet server that functions as a hub to the Intranet. The management believes that in addition to other advantages of using e-business technologies, the technological gap in manufacturing between the company and its counterparts in the developed world has reduced drastically. While it has been successful in exploiting the

\footnotetext{
${ }^{3}$ Plazas are intermediary service units that link up the manufacturer with dealers. Plazas provide technical support to dealers and do not normally offer services to end users
} 
B2B (business to business) segment of e-business technologies, however, the company has made little headway on the $\mathrm{B} 2 \mathrm{C}$ (business to consumer) front. Videocon attributes this to the general lack of awareness of the Internet in the society and the fact that the communication technology available to the general public is not powerful enough to download the hypertext related to various products.

Videocon has experienced several advantages in the adoption of e-business technology, for instance achieving a saving of $30 \%$ on transaction costs. It can be seen from Table1 that employment in the firm has registered an annual growth of $9.69 \%$ since 1994-95. It may be worth mentioning that several established consumer electronics firms (Texla Televisions, UPTRON) did not survive, even in the domestic market, due to competition from multinational corporations (MNCs) that entered the Indian market from 1991. Videocon, not only survived, but has maintained its market share. Its sales turnover has grown at $20.96 \%$ since $1994-95$. The company attributes the generation of indirect employment of about 5000 persons in its network of 1000 plazas to the adoption of e-business technologies.

\section{ii. $B P L$}

British Physical Laboratory (BPL) has been in existence for the past several decades. Having started as a consumer electronics firm in 1963, it diversified its operations to entertainment electronics, home appliances, electronic components, soft energy, health care, and power generation. However, the data presented in Table 1, Appendix I, and discussion in this subsection pertains to its entertainment electronics section. BPL was an early adopter of ICTs, from their initial entry on the Indian market. In addition to a network of more than 1500 dealers, BPL has more than fifty corporate office and service centres in the country. All offices, manufacturing plants, and important dealers are connected through satellite (VSAT).

The firm uses several modules of e-business technologies. COREMAN software, for instance, is used for process control in manufacturing, planning, procurement, and inventory management. The company has experienced several benefits of the adoption of e-business technologies. The Intranet has enhanced interactions with consumers through the network of service centres. This interaction has enabled the company to address problems more effectively and has also resulted in product quality improvements. The management of the company feels that while they may not have increased the market share, they have certainly been able to maintain it.

In terms of impact on employment and profitability, direct employment has grown at $9.61 \%$ while sales turnover has also increased significantly. The adoption of e-business technologies has contributed in the indirect employment of about 1500 persons. Adoption of portal based technologies along with improved product quality and better services has resulted in an annual 
growth of $20.63 \%$ in sales turnover since 1994-95. The company has not experienced any retrenchment of skilled and unskilled workforce due to adoption of its new business model. The company feels that while B2B e-business technologies are very productive, B2C has not been successful. It attributes this to socio-cultural norms, including the need to "touch and feel" products before buying them. On the financial front, e-transactions account for only $30 \%$ of all transactions.

\section{iii. ORIENT CRAFT}

Orient craft is the largest garment exporting firm in India and has maintained its position for several years. Established in 1978, the firm currently has eight branches located in and around Delhi. All the branches are connected through an Intranet using integrated service digital network (ISDN) line. Although this is a purely export oriented unit, it uses indigenously developed e-business technologies. There are two main components of e-business that are being used by the firm: first to interact with the foreign buyers and second with other business partners

in India. Remote login technologies are used for accessing the uniform resource locators (URLs) of foreign buyers to download designs, whereas Internet and Intranet technologies are used for coordination of activities with other branches of the company and raw material suppliers. The firm began to use CAD/CAM in the design and pattern making stages of garments manufacturing in 1992.

It can be seen from Table 1 that the firm has performed extremely well in international markets and registered a CAGR of sales turnover at $30.05 \%$. And the impressive employment growth of $16.67 \%$ is contrary to the general belief that the adoption of ICTs results in a reduction of jobs for unskilled workers. The management believes that its use of the enterprise resource planning (ERP) e-business module in personnel management, accounts, and documentation has significantly improved the performance of the firm. The application of SCM techniques has not only induced efficiency in business transactions with suppliers but has also created indirect employment for a few ICT professionals in supplier firms. Despite being a labour intensive sector firm, Orient Craft managers say they did not face any resistance from workers when implementing ICTs. In fact, the management attributes the impressive performance of the firm to the adoption of latest business models. 


\section{iv. GOKALDAS IMAGES}

Gokaldas Images is one of the top three garment manufacturing firms in India. The performance of the firm has steadily improved since its inception in 1972, and it has maintained its current position for a number of years. A multi-plant firm with 18 manufacturing plants located in Bangalore, Gokaldas Images introduced CAD/CAM technology in 1995. In 1997, the company set up a local area network (LAN) of 150 nodes in its headquarters. Email facilities were extended to all nodes in the same year. All the manufacturing plants are connected to the company Intranet using an ISDN line. The company has continued to adopt the latest garment manufacturing technologies as they become available, for instance importing a general sewing data (GSD) system from the UK in 1999. GSDs have been installed and integrated within the Intranet, a feature that has been very useful in the planning and monitoring of manufacturing activities in the various plants. The Internet is used to interact with foreign buyers and other business partners.

Additionally, the firm has recently begun to use the ERP software, STAGE, developed locally and exclusively for export oriented garment manufacturing units. The management believes that the e-procurement and electronic data interchange (EDI) modules of the software are likely to have a significant impact on the functioning of the firm. Despite severe competition in international markets, especially from China, the firm has been able to improve its performance. Table 1 shows that along with increasing sales turnover, employment opportunities have also increased. The management is of the opinion that it may not be possible to survive in international markets without the use of new technologies such as e-business. So far the company has not encountered any adverse impacts in the adoption of new ICTs on the firm. However, there is no evidence to show that proximity to technology providers has had any impact on ICT adoption by the firm. It is noteworthy that the company's base, Bangalore, is often referred to as the electronic capital of India and is reputed for providing software solutions to a large number of firms located in the US, UK, and other developed countries.

\section{v. SONAL GARMENTS}

This multi-plant firm was established in 1976. At present it has manufacturing plants in Salem, Tiruppur, Bangalore, and Delhi, while its corporate office is in Mumbai. Although, the company's headquarters is fully computerized with LAN in place, the firm has not linked up its manufacturing plants through an Intranet. The company primarily uses the Internet for coordinating the business activities of manufacturing units and maintains a company website. The firm uses remote login technology to interact with foreign buyers. The management of the 
firm admits that pressure from buyers has been the driving force behind the adoption of new technologies. The firm uses Internet very effectively for searching new buyers and participates in Internet bidding for contracts.

With regard to impact on e-business technologies, the management claims that in addition to contributing to product design (including the use of CAD/CAM) and augmenting the productivity of workers, the adoption of remote login technologies has reduced transaction costs by around $30-40 \%$. The failure to link up all the manufacturing units, which are spread out across the country, has been attributed to long distances coupled with inadequate communications infrastructure. Connecting all units will require a huge investment in private telecommunication network that may not be economically viable. As with the other garments firms, Sonal says it has not experienced any negative impacts of the adoption of e-business technologies. 



\section{ADOPTION OF E-BUSINESS TECHNOLOGIES AND THEIR CONSEQUENCES}

Every technological development has a gestation period. ICTs, being very pervasive technologies, have been the fastest growing technologies in the past decade and adopters expected a dramatic impact on their performance. Similar to the productivity paradox associated with the first wave of ICTs before the early 1990s, however, the impact of e-business technologies has also been ambiguous (Hecker, 2001; Pohjola, 2001). Nevertheless, this study did not find any evidence to support the argument that adoption of e-business technologies leads to a loss of jobs. The impact of ICTs on producers as well as consumers is discussed separately.

\subsection{Producers}

The Indian ICT industry in general has experienced an average growth of 55\% in the last 10 years. Indian producers of these new technologies have mainly concentrated on international markets. This is because the penetration of e-business technologies in India firms has been very low due to infrastructure related problems. Indian IT firms have not only substantially contributed to foreign exchange but have also created huge employment opportunities. The results of the study show that the growth of employment in sample firms ranged 34 to $48 \%$ between 1994-95. The Indian IT sector in general has recorded the highest growth after the liberalization of Indian economy. Indian producers of e-business technologies have generally focused on customized rather than packaged software solutions. This could be due to lack of experience, required expertise, and the competition from multinationals such as SAP. The companies have made satisfactory progress, however, in customized software product and services. Although the contribution of the Indian IT industry to GDP is still very small, its impact on the Indian economy is visible.

\subsection{Consumers}

\section{Performance}

Until the 1990s, the domestic market had been protected for Indian companies in the consumer electronics sector. There was hardly any competition in the sector. The scenario changed after

the 1990s when the domestic market was opened to foreign firms. Several large firms 
disappeared from the market, as they could not withstand the competitive pressure. MNCs entering the Indian market, such as LG and Samsung, enjoyed several technological advantages in addition to other intangible assets such as reputation and brand name. However, the firms that have been discussed in this study have not only survived but have improved their performance in the domestic and international markets. Indian companies that responded to the new environment by adopting new technologies were able to survive and face new challenges. The impressive growth in sales turnover of the sample firms suggests that the adoption of ICTs has not only enabled firms to remain in the market but has been catalytic in improving their performance.

\section{Employment}

The general impression in foregoing studies on this subject is that the productivity gains associated with the adoption of ICTs are derived from retrenchment of the workforce. The literature further suggests that the adoption of ICTs is not always focussed on productivity gains but could be aimed at appropriating other benefits of new technologies. However, some studies (Kramarz, 1998; Doms et al., 1997) find evidence of structural changes in employment following the adoption of ICTs. The results of this study show that there has been significant growth of employment in all the sample firms. In this study, however, we have not been able to analyse the impact of e-business technologies on the structural changes in employment. During our discussions at firm level, it was suggested that the major growth in employment has been for skilled workers. In general, the study did not find any evidence to suggest that the adoption of ebusiness technologies has resulted in the loss of jobs. 


\section{SUMMARY AND CONCLUSIONS}

The study aimed at analyzing the pattern of the adoption of e-business technologies in large corporations in India and its impact on employment. Case studies were used to examine various issues related to the use of e-business technologies in three sectors, namely: ICT producing firms, consumer electronics, and garment manufacturing. The top few firms in each sector, based on their performance over several years, were selected. We have used data covering a period of nine years, 1994-95 to 2003-04 in the analysis.

The findings of the study suggest that the pattern of adoption of e-business technologies has not been uniform across industries. However, the pattern of adoption within sectors has been similar. The consumer electronics firms surveyed adopted these technologies more or less in all business activities such as production, marketing, coordination, supply chain management, and customer relation management. Garment manufacturing firms, on the other hand, adopted email and internet for interacting with buyers and $\mathrm{CAD} / \mathrm{CAM}$ technologies in manufacturing process. A common feature across both the sectors is that both have adopted B2B e-business models. The B2C model has been neglected, even by the consumer electronics sector. The firms attributed socio-economic factors and a lack of institutional infrastructure for the failure to adopt the B2C model.

The data provided by sample firms suggests that the adoption of these technologies has not only enabled firms to survive in the domestic as well as in international markets but has also contributed to better performance. The firms started adopting new technologies with the liberalization of Indian economy in 1991. Firms might have adopted ICTs due to competitive pressures from MNCs that were allowed to enter into the Indian market in 1991. In addition to achieving a high growth rate, the employment opportunities have increased significantly. The average growth in the sales turnover of sample firms was $25 \%$, while firm level employment has registered a growth rate of $13 \%$ since 1994-95. All the sample firms reported that the adoption of these technologies has also created indirect employment, which varies according to the size of firm and type of industry. These findings are in accordance with the existing literature (Hecker, 2001; Kramarz, 1998; Lal, 1996 \& 2002). The findings of this study suggest that concepts of resource-based theory and the role of competition can contribute to understanding the patterns of adoption of e-business technologies.

However, the study provides no evidence to suggest that the use of new technologies have adverse effects on firms. Their adoption could, nevertheless, lead to changes in the employment structure as technological change associated with the adoption of ICTs is regarded as primarily 
skills-biased (Doms et al., 1997). The impressive growth of sales turnover and employment of sample firms may not be fully attributed to the adoption of e-business technologies, however. Other measures that have been taken since 1991 such as simplified import procedures for raw materials and machinery might have played a role. Hence the findings of the study need to be interpreted against the backdrop of other economic policies. Another limitation of the study, linked to the small sample size, is the lack of statistical tests of the significance of factors that influenced the adoption of e-business technologies. Further research is needed to examine the impact of e-business technologies on firm-specific factors such as productivity, quality improvement, and conduct of firms. 


\section{REFERENCES}

Acero, Liliana, 1995, "Conflicting demands of new technology and household work: women's work in Brazilian and Argentinian textiles", in: Swasti Mitter and Sheila Rowbotham (Eds.), Women Encounter Technology: Changing Patterns of Employment in the Third World, London and New York: Routledge, 70-92.

Ayres, R. U., 1991, Computer Integrated Manufacturing, vol. 1, London: Chapman \& Hall.

Card, D., Kramarz, F. and T. Lemieux, 1997, "Changes in relative structure of wages and employment: A comparison of United States, Canada, and France", NBER Working Paper 5487.

Doms, M., Dunne, T. and K.R. Troske, 1997, "Workers, wages and technology", Quarterly Journal of Economics, CXII(February):253-90.

Freeman, C. and Luc Soete, 1985, "Information Technology and Employment: An Assessment", Sussex: Science Policy Research Unit.

Hecker, Daniel E., 2001, "Employment Impact of Electronic Business", Monthly Labour Review, May, 1-16.

James, Jeffrey, 1994, "Microelectronics and the Third World", in: Charles Cooper (Ed.), Technology and Innovations in the International Economy, Tokyo: United Nations University, pp. 149-230.

Kramarz, F., 1998, “Computers and Labour Markets: International Evidence”, in: Matti Pohjola, ed., Information Technology, Productivity, and Economic Growth: International Evidence and implications for Economic Development, New York: Oxford University Press, 99-118.

Kuwahara, Y., 1984, "Creating New Jobs in High-Technology Industries”, Paper presented at OECD Inter-Governmental Conference on Employment and Growth in the Context of Structural Change, Paris, OECD.

Lawrence, Robert Z., 1984, The Employment Effects of the New Information Technologies: An Optimistic View, The Brookings Institution mimeo

Lal, K., 1996, "Information Technology, International Orientation and Performance : A case study of electrical \& electronic goods manufacturing firms in India", Information Economics and Policy 8(3):269-80.

Lal. K. 2002, "E-business and Manufacturing Sector: A Study of Small and Medium-sized Enterprises in India", Research Policy, 2002, 31(7): 1199-1211.

Leontief, Wassily and Faye Duchin, 1983, The Impact of Automation on Employment, USA: National Science Foundation.

Nilsen, S.E., 1980, "Microelectronics: Useful for some, harmful for others", Social Science Information, 19(2):79-101. 
Peitchinis, S., 1984, Computer Technology and Employment: Retrospect and Prospect, London: St. Martin's Press

Rada, J.F., 1982, "The impact of microelectronics and information technology : Case studies in Latin America", UNESCO Publication, Vendome, Imprimerie Presses Universitaires de France.

Rahim, S. A. and A. J. Pennings, 1987, Computerization and Development in South East Asia (Asian Mass Communications Research and Information Centre, Singapore).

Talero, E. and P. Gaudette, 1995, "Harnessing information for development: A proposal for a World Bank group strategy", Discussion Paper No. 313, The World Bank. 


\section{THE UNU-INTECH DISCUSSION PAPER SERIES}

\#2004-16 Growth of Employment and the Adoption of E-business By Kaushalesh Lal

\#2004-15 Learning, Innovation And Cluster Growth: A Study Of Two Inherited Organizations In The Niagara Peninsula Wine Cluster By Lynn K. Mytelka and Haeli Goertzen

\#2004-14 Determinants of E-business Adoption: Evidence from Firms in India, Nigeria, Uganda By Banji Oyelaran-Oyeyinka and Kaushalesh Lal

\#2004-13 Agricultural Biotechnology: Issues for Biosafety Governance in Asian Countries ByPadmashree Gehl Sampath

\#2004-11 Demanding Stronger Protection for Geographical Indications: The Relationship between Local Knowledge, Information and Reputation By Dr Dwijen Rangnekar

\#2004-10 Are Foreign Firms More Productive, and Export and Technology Intensive than Local Firms in Kenyan Manufacturing? By Rajah Rasiah and Geoffrey Gachino

\#2004-9 Learning New Technologies by SMEs in Developing Countries By Banji Oyelaran-Oyeyinka and Kaushalesh Lal

\#2004-8 Building Research Capacity in Social Sciences for Development in Bolivia: A Case of Institutional Innovation By Prof. Léa Velho, Maria Carlota de Souza Paula, Roberto Vilar

\#2004-7 Sectoral Pattern of E-business Adoption in Developing Countries By Banji Oyelaran-Oyeyinka and Kaushalesh Lal

\# 2004-6 Non-Tariff Measures, Technological Capability Building and Exports in India’s Pharmaceutical Firms By Frederick Nixson and Ganeshan Wignaraja

\# 2004-5 Technological Intensity and Export Incidence: A Study of Foreign and Local Auto-Parts, Electronics and Garment Firms in Indonesia By Rajah Rasiah

\# 2004-4 Science and Technology in Latin America and the Carribean: An Overview by Léa Velho

\# 2004-3 Coping with Globalisation. An Analysis of innovation capability in Brazilian telecommunications equipment industry by Sunil Mani

\# 2004-2 Learning and Local Knowledge Institutions in African Industry by Banji Oyelaran-Oyeyinka, January 2004

\# 2004-1 Productivity, Exports, Skills and Technological Capabilities: A Study of Foreign and Local Manufacturing Firms in Uganda by Rajah Rasiah and Henry Tamale, January 2004

\# 2003-12 Regulation of Foreign Investment in Historical Perspective by Ha-Joon Chang, December 2003

\# 2003-11 Illusory Competitiveness: The Apparel Assembly Model of the Caribbean Basin by Michael Mortimore, November 2003

\# 2003-10 The Role of Market, Trust and Government in the Development of the Information Hardware Industry in Taiwan By Rajah Rasiah and Yeo Lin, October 2003

\# 2003-9 Growth Theories Revisited: Enduring Questions with Changing Answers By C. V. Vaitsos, October 2003

\# 2003-8 Designing National Regimes that Promote Public Health Objectives By Padmashree Gehl Sampath, September 2003

\# 2003-7 FDI-facilitated Development: The Case of the Natural Gas Industry of Trinidad and Tobago. By Lou Anne A. Barclay, September 2003

\# 2003-6 Sources of Training in African Clusters and Awareness of ICTs: A Study of Kenya and Ghana By Catherine Nyaki Adeya, September 2003 
\# 2003-5 The Internet Diffusion in Sub-Saharan Africa: A cross-country Analysis By Banji OyelaranOyeyinka and Kaushalesh Lal, July 2003

\# 2003-4 Defining an Intellectual Property Right on Traditional Medicinal Knowledge: A ProcessOriented Perspective By Padmashree Gehl Sampath, July 2003

\# 2003-3 New Wave Technologies: Their Emergence, Diffusion and Impact. The Case of Hydrogen Fuel Cell Technology and the Developing World By Lynn K. Mytelka, July 2003

\# 2003-2 Systems of Innovation and Human Capital in African Development By Banji OyelaranOyeyinka and Lou Anne Barclay, May 2003

\# 2003-1 Deregulation, Entry of MNCs, Public technology procurement and Innovation Capability in India's Telecommunications Equipment Industry By Sunil Mani, February 2003

\# 2002-10 Moving Up Or Going Back The Value Chain an Examination of The Role of Government With Respect to Promoting Technological Development in The Philippines By Sunil Mani, November 2002

\# 2002-9 Research Capacity Building in Nicaragua:From Partnership with Sweden to Ownership and Social Accountability By Léa Velho, October 2002

\# 2002-8 R\&D in the Public and Private Sector in Brazil: Complements or Substitutes? By Lea Velho and Tirso W. Saenz, July 2002

\# 2002-7 Systemic Coordination and Human Capital Development: Knowledge Flows in Malaysia's MNC-Driven Electronics Clusters By Rajah Rasiah, June 2002

\# 2002-6 What is the 'Knowledge Economy'? Knowledge Intensity and Distributed Knowledge Bases By Keith Smith, June 2002

\# 2002-5 Internet Access in Africa: an Empirical Exploration By Banji Oyelaran-Oyeyinka and Catherine Nyaki Adeya, May 2002

\# 2002-4 Institutional Support for Investment in New Technologies: The Role of Venture Capital Institutions in Developing Countries by Sunil Mani and Anthony Bartzokas, May 2002

\# 2002-3 Manufacturing Response in a National system of Innovation: Evidence from the Brewing Firms in Nigeria By Banji Oyelaran-Oyeyinka, April 2002

\# 2002-2 Prospects for the Digital Economy in South Africa: Technology, Policy, People, and Strategies By Derrick L. Cogburn \& Catherine Nyaki Adeya, April 2002

\# 2002-1 TRIPs and Capability Building in Developing Economies by Rajah Rasiah, March 2002 